\title{
CEDERA OLAHRAGA DALAM PERSPEKTIF TEORI MODEL EKOLOGI
}

\author{
Oleh: Yustinus Sukarmin \\ Dosen Jurusan Pendidikan Kesehatan dan Rekreasi \\ FIK UNY
}

\section{Abstrak}

Semua aktivitas manusia, termasuk olahraga, penuh dengan risiko atau bahaya. Seiring dengan meningkatnya aktivitas olahraga meningkat pula risiko atau bahaya tersebut. Sekecil apa pun risiko atau bahaya yang ada dalam aktivitas olahraga, jika diabaikan atau tidak ditangani dengan sungguh-sungguh dan tidak dapat dikendalikan sepenuhnya akan menimbulkan kecelakaan dengan segala akibat yang merugikan manusia, di antaranya cedera.

Cedera yang terjadi pada waktu seseorang melakukan aktivitas fitness, latihan, atau pertandingan olahraga, - kemudian disebut cedera olahraga meliputi sistem muskulosekeletal. Ada dua tipe cedera olahraga, yaitu: cedera akut dan cedera kronis. Patah tulang, memar, robek ligamen, robek otot atau tendo, lecet, dan tergores adalah beberapa contoh cedera akut, sedangkan stress fractures, tendinitis, dan epifisitis atau apofisitis merupakan sebagian contoh cedera

Menurut teori keselamatan, kecelakaan (cedera) itu dapat dicegah atau dihindari. Untuk mencegah terjadinya cedera olahraga secara akurat, orang harus tahu penyebabnya. Agar kejadian serupa tidak terulang kembali, penyebab terjadinya kecelakaan (cedera) harus dihilangkan atau dikendalikan. Teori model ekologi mengatakan kecelakaan terjadi karena ada interaksi yang dinamis antara dua faktor, yaitu faktor manusia (intrinsik) dan faktor lingkungan (ekstrinsik). Oleh sebab itu, penanganan terhadap faktor penyebab terjadinya kecelakaan (cedera) harus dilakukan secara terpadu, artinya kedua-duanya harus mendapatkan perhatian.

Kata kunci: cedera olahraga, model ekologi. 
Antusiasme masyarakat melakukan kegiatan olahraga sejak ada "boom" olahraga lari pada tahun 1970 mengalami peningkatan. Masyarakat mulai menyadari manfaat yang dapat diperoleh melalui aktivitas olahraga, seperti: senam aerobik, renang, bersepeda, tenis, basket, dan aktivitas olahraga lainnya. Seiring dengan meningkatnya partisipasi masyarakat dalam berbagai aktivitas olahraga, meningkat pula kecelakaan yang mengakibatkan cedera (Taylor, 1997: ix).

Semua aktivitas manusia, termasuk olahraga, penuh dengan risiko-bahaya yang dapat mendatangkan kecelakaan. Setiap unsur yang terkait dengan kegiatan olahraga tidak ada yang tidak berisikq: dari alat, fasilitas, proses, tempat, sampai dengan cuaca. Cedera karena melakukan olahraga baru merupakan sebuah "kemungkinan", seperti dikatakan Cortes yang disitir oleh Ritzei (2003: 1), "risk is the probability that in the presence of a certain danger, damage takes place." Meskipun demikian, orang tidak dapat mengabaikan keberadaan sebuah risiko dari kegiatan olahraga begitu saja.

Sekecil apa pun cebuah risiko, jika tidak ditangani dengan sungguhsungguh dan tidak berhasil dikendalikan akan menimbulkan kecelakaan dengan segala akibat yang merugikan manusia. Menurut Merki (1996: 484), “accidents are major cause of death among young people... Although many accidents that young people have are not fatal, they can cause serious problems." Terkait dengan kasus kecelakaan pada saat berolahraga, Azrul Ananda (2002: 20) mengatakan sekitar empat juta anak di Amerika Serikat setiap tahun dibawa ke Unit Gawat Darurat karena mengalami cedera pada saat berolahraga. Namun demikian, trauma yang mereka alami tidak terlampau parah. Menurut data dari Akademi Bedah Ortopedi Amerika, sekitar 95 persen cedera olahraga yang dialami anak-anak meliputi luka iris, lecet, memar, cedera otot, dan beberapa kondisi serupa.

Diberitakan bahwa Taufik Hidayat, pebulutangkis Indonesia, terpaksa mengubur impiannya untuk menjuarai All England 2005 setelah menderita cedera lutut. Kasus ini menyusul cedera yang dialami yuniornya, yaitu Sony Dwi Kuncoro dan Simon Santosa, yang lebih dahulu membatalkan keikutsertaannya dalam turnamen tersebut karena menderita cedera kaki. Masih banyak kasus serupa yang menimpa para atlet baik dari dalam negeri maupun luar negeri. Andriy Shevchenko, pemain sepakbola AC Milan, terpaksa harus absen dalam beberapa pertandingan menyusul cedera retak tulang pipi dan rongga mata yang nyaris merenggut nyawanya setelah berbenturan dengan Simone Loria, bek Cagliari (Dwi Widijatmiko, 2005: 7). 
Untuk dapat menikmati aktivitas fisik seseorang harus terbebas dari cedera dan penyakit. Ketidakmampuan seseorang dalam melakukan aktivitas oìahraga disebabkan oleh adanya cedera yang dialaminya. Usaha keras seorang atlet dengan menghabiskan waktunya berbulan-bulan, bahkan bertahun-tahun untuk menjalani program latihan yang berat akan musnah dalam beberapa detik karena mengalami cedera. Dalam permainan tim, jika seorang pemain kunci mengalami cedera, peluang untuk meraih kemenangan menjadi tipis.

Artikel ini membicarakan hal-hal yang berkaitan dengan cedera olahraga yang dapat terjadi pada setiap orang pada waktu berpartisipasi dalam olahraga, tanpa memandang status, jenis kelamin, dan usia. Dalam pembahasan selanjutnya akan dijelaskan pengertian cedera olahraga, macam-macam cedera olahraga, penyebab terjadinya cedera olahraga, dan pencegahan cedera olahraga yang difokuskan pada sudut pandang teori model ekologi.

\section{CEDERA OLAHRAGA}

Olahraga mempunyai peranan utama dalam perjuangan hidup dan memberikan pengalaman yang bernilai dan nyata. Tekanan lingkungan dan manusia yang diterima oleh seseorang pada waktu berolahrasa sering menimbulkan kecelakaan atau cedera. Hal ini kadang-kadang dapat mempengaruhi, bahkan mengubah kehidupan manusia.

Dalam arti umum cedera adalah kerusakan atau luka yang dialami atau diderita oleh seseorang. Dengan demikian, cedera olahraga dapat diartikan sebagai cedera yang terjadi pada waktu seseorang melakukan aktivitas fitness, latihan, atau pertandingan olahraga Congeni, 2004: 1; Dunkin, 2004: 2). Kendatipun setiap bagian tubuh dapat mengalami cedera pada waktu melakukan olahraga atau latihan, istilah cedera olahraga selalu ditujukan pada cedera yang meliputi sistem muskulosekeletal.

Cedera olahraga banyak jenisnya dan dapat dikelompokkan atas dasar tempat, proses, dan waktu terjadinya cedera (Rusli Lutan, 2001: 43). Berdasarkan tempat terjadinya, cedera olahraga dibedakan menjadi cedera jaringan lunak dan cedera jaringan keras. Cedera jaringan lunak adalah cedera pada otot, saraf, tendo, ligamen, kulit, pembuluh darah, dll., sedangkan cedera jaringan keras adalah cedera pada tulang, berupa retak atau patah seluruhnya.

Jika dilihat dari proses terjadinya, cedera olahraga dibedakan menjadi cedera tumbukan, cedera pelintiran, dan cedera gesekan. Cedera tumbukan adalah 
cedera yang terjadi karena tubuh berbenturan dengan benda keras, seperti alat olahraga, lapangan, atau lawan. Cedera yang terjadi karena tubuh melakukan gerakan berputar disebut cedera pelintiran, seperti melakukan gerakan pivot pada sepakbola atau bola basket. Yang dimaksud dengan cedera gesekan adalah cedera yang terjadi karena tubuh terkena gesekan permukaan yang kasar, misalnya sliding dalam sepakbola atau softball. Gerakan ini akan menyebabkan kulit terkelupas.

Berdasarkan waktu terjadinya, cedera olahraga dibedakan menjadi cedera akut dan cedera kronis atau overuse. Yang dimaksud dengan cedera akut adalah cedera yang disebabkan oleh trauma seketika, misalnya melakukan across-body block dalam football. Yang termasuk cedera ini antara lain: patah tulang, memar, robek ligamen, robek otot atau tendo, lecet, dan tergores. Cedera kronis adalah cedera yang disebabkan oleh aktivitas yang dilakukan berulang-ulang dalam waktu lama, seperti: lari, lemparan overhand, atau servis tenis. Cedera ini meliputi, antara lain: stress fracture, tendinitis, dan epifisitis atau apofisitis (Congeni, 2002: 2).

Kadang-kadang orang berpikir bahwa hanya punggung atau lengan dan tungkai yang mungkin terkena cedera pada waktu melakukan olahraga atau aktivitas fisik lainnya. Cedera olahraga dapat mengenai seluruh bagian tubuh manusia, seperti: muka, leher, kepala, tangan, kaki, dan organ seks dengan klasifikasinya. Giam (1993: 137) membedakan cedera olahraga berdasarkan tingkatannya menjadi tiga, yaitu:

1. Cedera ringan merupakan cedera dengan robekan yang hanya dapat dilihat dengan mikroskop, sedikit keluhan, dan tidak mengganggu performance atlet, misalnya: lecet, memar, atau robek ligamen kecil.

2. Cedera sedang adalah cedera dengan kerusakan jaringan, menimbulkan rasa nyeri, bengkak, merah, atau panas dengan menimbulkan gangguan fungsi dan punya pengaruh pada performance atlet, misalnya: robek otot dan robek ligamen.

3. Cedera berat yaitu cedera dengan robekan otot atau ligamen secara lengkap atau hampir lengkap atau faktur tulang yang memerlukan istirahat total, pengobatan intensif, bahkan operasi. 


\section{PENYEBAB CEDERA OLAHRAGA}

Kecelakaan atau cedera bukan sesuatu yang terjadi begitu saja, melainkan ada penyebabnya. Rusli Lutan (2001: 43) mengatakan bahwa semua atlet, baik pemula maupun yang sudah berprestasi, terutama remaja dan anak-anak yang belum berkembang keterampilannya mempunyai potensi mengalami cedera. Menurut Bompa (200: 100) cedera disebabkan oleh kurangnya pengetahuan tentang latihan dan penambahan beban secara tepat, sikap tubuh yang salah pada waktu mengangkat beban, dan lemahnya otot perut.

Pendapat lain mengatakan bahwa cedera yang terjadi pada waktu berolahraga disebabkan oleh beberapa hal, yaitu: (1) kecelakaan, (2) pelaksanaan latihan yang kurang baik, (3) peralatan yang tidak sesuai, (4) kurang persiapan kondisi fisik, dan (5) pemanasan dan peregangan yang tidak memadai (Dunkin, 2004: 2). Pendapat senada disampaikan oleh pakar lainnya yang mengatakan bahwa penyebab terjadinya cedera olahraga adalah: (1) latihan yang tidak baik, (2) pemakaian perlengkapan keselamatan yang kurang sesuai, dan (3) pemakaian alas kaki yang tidak cocok atau tidak sesuai (Congeni, 2004: 1).

Adanya tekanan dari pihak luar, seperti: harapan orang tua dan coach yang berlebihan tanpa memperhatikan keterbatasan atlet, baik fisik maupun teknik, dapat menjadi salah satu penyebab terjadinya cedera (Asrul Ananda, 2002: 20). Atlet yang masih muda terpaksa tetap meneruskan permainannya walaupun harus menahan sakit, karena takut dimarahi oleh orang tiua atau coach yang mengharapkan dirinya menjadi juara. Rasa sakit atau kram yang timbul pada saat orang melakukan olahraga merupakan "bahasa tubuh" untuk memberitahukan bahwa ada sesuatu yang salah (Congeni, 2004: 5). Jika ini diteruskan, orang tersebut akan mengalami cedera yang mungkin dapat menghancurkan masa depannya sendiri.

Khoiron Fadil (2002: 7) menuding wasit sebagai biang keladi terjadinya cedera pada pemain sepakbola karena tidak dapat melaksanakan tugas memimpin pertandingan dengan baik. Keragu-raguan dan ketidaktegasan wasit pada waktu memimpin pertandingan memberikan angin bagi pemain untuk berbuat curang dengan mencederai lawan. Bambang Pamungkas menderita retak engkel kaki kirinya setelah ditebas oleh Agus Setiawan dalam sebuah pertandingan yang keras menjurus kasar di stadion Lebak Bulus. Kasus serupa menimpa Nurul Huda yang mengalami patah tulang kering setelah ditekel secara keras oleh Andi Sutrisno. 


\section{PENCEGAHAN CEDERA OLAHRAGA}

Orang akan menderita dan mungkin putus asa karena kehilangan masa depan dengan cedera yang dialaminya. Kendatipun demikian, orang tidak boleh merasa pesimis, apalagi takut berolahraga, karena pada prinsipnya kecelakaan (cedera) itu dapat dicegah. Untuk mencegah kecelakaan dibutuhkan tanggung jawab dari setiap individu secara terus menerus dan kesiapsiagaan terhadap kebutuhan keselamatan (Creighton, 1974: 59). Setiap cabang olahraga memerlukan kebutuhan keselamatan'yang sama atau hampir sama.

Menurut Bethesda (2001: 4) untuk menurunkan risiko terjadinya cedera perlu dilakukan tindakan preventif. Pendapat senada disampaikan oleh Congeni (2004: 1) yang mengatakan bahwa cara terbaik untuk menghadapi cedera olahraga adalah dengan mencegahnya. Huisenga (2004: 1) menambahkan bahwa memakai perlengkapan pada waktu berolahraga atau melakukan aktivitas lainnya merupakan kunci untuk mencegah cedera.

Oleh Congeni (2002: 3) tindakan preventif untuk mencegah terjadinya cedera olahraga dijabarkan secara rinci, sebagai berikut:

1. Mempunyai kondisi fisik yang baik pada waktu berolahraga.

2. Mengetahui dan melaksanakan aturan main.

3. Menggunakan alat pelindung yang sesuai dan baik.

4. Mengetahui cara menggunakan peralatan olahraga.

5. Melakukan pemanasan sebelum berolahraga.

6. Tidak berolahraga pada waktu mengalami kelelahan atau sedang sakit.

Gayut dengan pendapat di atas, Creighton (1974: 29) menganjurkan langkah-langkah yang harus dilakukan untuk menghindari terjadinya kecelakaan yahg dapat menimbulkan cedera, yaitu: (1) mengetahui keterampilan dengan benar, (2) memahami dan menerapkan peraturan permainan, (3) memakai pelindung yang sesuai, (4) memelihara peralatan agar tetap dalam kondisi baik, dan (5) fisik dalam keadaan fit, terutama untuk berolahraga.

Semua tindakan pencegahan yang dikemukakan oleh para pakar tersebut di atas dilakukan sebelum kecelakaan terjadi. Tindakan pencegahan yang demikian ini oleh Florio (1979: 36) disebut tindakan pencegahan primer. Di samping itu, ada tindakan pencegahan yang dilakukan setelah kecelakaan terjadi dalam rangka meminimalkan kemungkinan akibat yang ditimbulkan oleh kecelakaan yang disebut dengan tindakan pencegahan sekunder. Tindakan pencegahan sekunder berupa pemberian P3K yang dilakukan secara profesional. 
Setelah itu, dilanjutkan dengan tindakan pencegahan tersier untuk membatasi ketidakmampuan dengan rehabilitasi.

\section{TEORI MODEL EKOLOGI}

Pada bagian sebelumnya telah dijelaskan bahwa cedera olahraga tidak terjadi begitu saja, tetapi ada penyebabnya. Untuk mencegah terulangnya kembali peristiwa serupa, orang harus melakukan tindakan dengan meniadakan faktorfaktor penyebab tersebut. Menurut teori model ekologi kecelakaan atau cedera disebabkan oleh faktor manusia dan faktor lingkungan (Florio, 1979: 42). Dari beberapa penelitan diperoleh informasi bahwa $85 \%$ kecelakaan disebabkan oleh faktor manusia dan $15 \%$ kecelakaan disebabkan oleh faktor di luar manusia.

Menurut model ekologi (Gambar 1), kecelakaan tidak dapat disebabkan hanya oleh satu faktor saja. Kecelakaan sering disebabkan oleh satu tindakan atau kondisi, seperti kecepatan tinggi (ngebut), keadaan mabuk (intoksikasi), atau jalan basah dan licin. Walaupun semua ini dapat menjadi faktor pendukung dalam kecelakaan lalu lintas di jalan raya, mereka tidak dapat secara tepat dikatakan "penyebabnya". Banyak orang berkendaraan dengan kecepatan tinggi, menjalankan mobil dalam keadaan mabuk, berjalan di jalan yang basah dan licin tanpa mengalami kecelakaan.

Kecelakaan tidak dapat hanya disebabkan oleh tingkah laku tidak aman, tetapi juga oleh lingkungan tidak aman sekaligus (Creighton, 1974: 8). Pendapat ini diperkuat oleh Brody, seperti dilansir oleh Yost (1970: 14) bahwa kecelakaan itu terjadi sebagai akibat adanya ketidakharmonisan fungsional atau ketidakseimbangan antara manusia dan lingkungannya. Dengan demikian, kecelakaan merupakan hasil interaksi dinamis antara faktor manusia (intrinsik) dan faktor lingkungan (ekstrinsik).

Faktor intrinsik sebagai penyebab kecelakaan meliputi kelemahan fisik, penglihatan yang tidak baik, stres, kelelahan, distraktibilitas, kurang pengetahuan, sikap yang tidak baik, kebiasaan yang tidak baik, dan perasaan aman yang palsu. Faktor lainnya, yakni faktor ekstrinsik sebagai penyebab kecelakaan terdiri atas keadaan cuaca yang jelek, terlalu ramai, peralatan yang rusak, pelaksanaan hukum yang tidak baik, lingkungan sosial yang tidak mendukung, peraturan yang tidak memadai, dan kurang pendidikan keselamatan.

Beberapa faktor penyebab terjadinya cedera olahraga yang telah dikemukakan oleh para pakar di atas menurut teori model ekologi dapat dikelompokkan ke dalam dua faktor, yaitu faktor manusia dan faktor lingkungan. 
Faktor manusia yang menjadi penyebab terjadinya cedera, antara lain, meliputi: kurangnya pengetahuan tentang aktivitas yang dilakukan, tidak memiliki keterampilan yang memadai, tidak dalam kondisi fisik yang baik, kurang pemanasan dan peregangan, dan tidak memakai alat pelindung yang sesuai. Faktor di luar manusia atau faktor lingkungan yang menjadi penyebab terjadinya cedera; antara lain, meliputi: alat dan fasilitas olahraga yang tidak baik, alat pelindung dan perlengkapan yang tidak sesuai, program latihan yang tidak tepat, dan peratuan yang tidak dilaksanakan dengan baik.

Hubungan ekologi itu bersifat kompleks, sehingga pencegahan tidak akan berhasil bila usaha untuk remedinya difokuskan terlalu sempit pada satu pemecahan saja. Usaha-usaha pencegahan kecelakaan sering selalu dipermudah dan secara eksklusif diarahkan pada pengontrolan faktor-faktor ekstrinsik. Modifikasi faktor manusia juga harus dilakukan, jika program-program pencegahan kecelakaan ingin sungguh-sungguh efektif. Satu-satunya pendekatan rasional terhadap penyebab ganda adalah sebuah :nncangan program yang diarahkan kenada pemecahan ganda.

Di dalam diagram model ekologi ada empat komponen yang menjadi faktor penentu terjadinya kecelakaan. Komponen-komponen dimaksud adalah:

1. Kondisi tidak aman adalah keadaan sekitar tempat betlangsungnya suatu kejadian, seperti: lapangan berlubang, hari hujan, dan penonton penuh sesak.

2. Kejadian tidak aman adalah kejadian ekstrinsik yang tidak diketahui sebelumnya, misalnya: bola pecah, gawang roboh, dan berhenti mendadak.

3. Keadaan tidak aman adalah jumlah keseluruhan tekanan psikologis, emosi, dan fisik manusia, misalnya: marah, stres, dan takut.

4. Tindakan tidak aman adalah tanggapan perilaku individu terhadap rangsang - yang berorientasi pada tujuan yang relevan. Ini dapat diilustrasikan dalam pertandingan sepakbola, seorang pemain bermain keras menjurus kasar bahkan tidak segan-segan mengasari lawan agar dapat memenangi pertandingan. 


\section{Penyebab Kecelakaan}

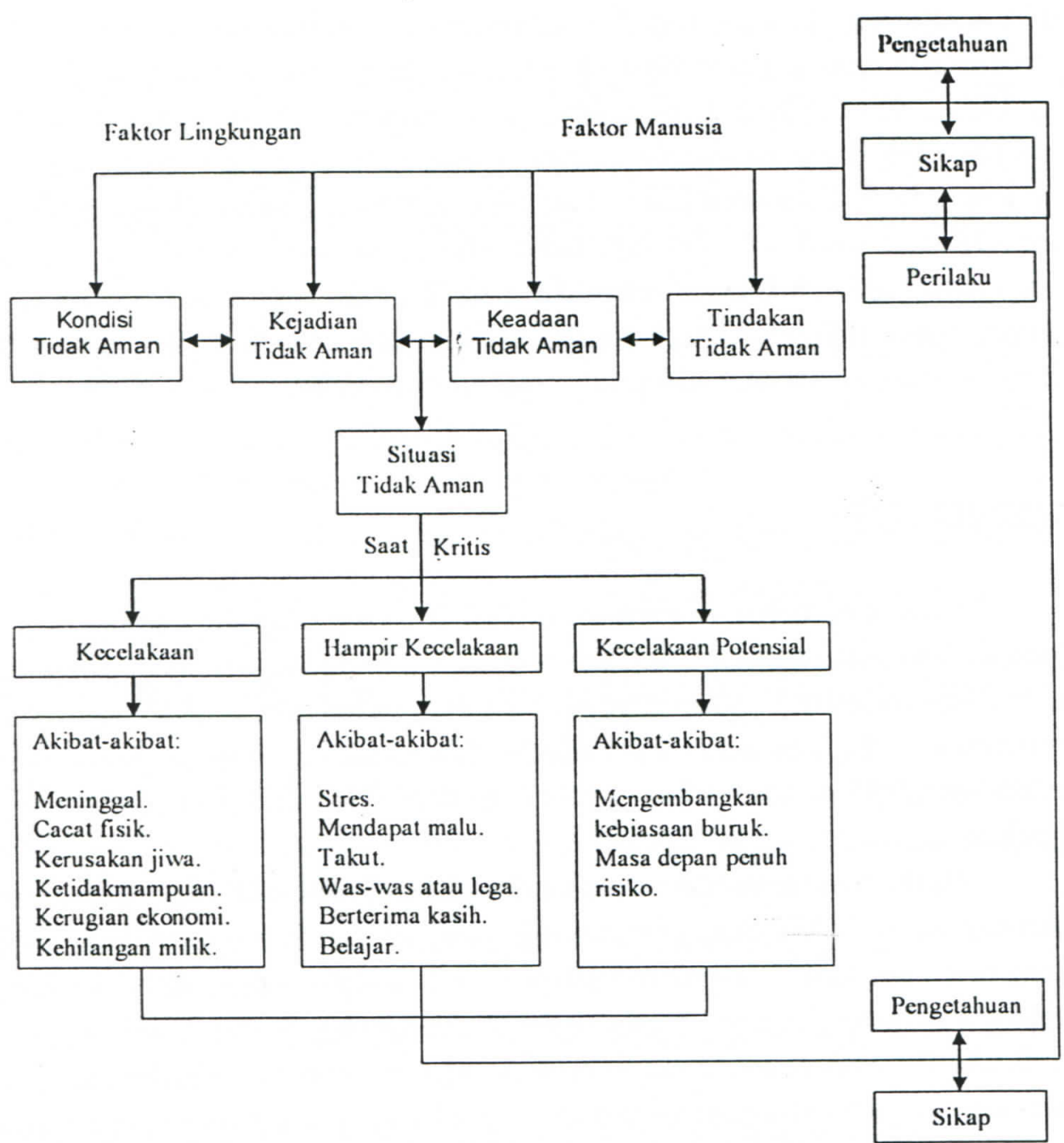

Gambar 1. Model Ekologi Penyebab Kecelakaan

(Sumber: Florio, 1979: 43)

Keempat penyebab yang tidak aman tersebut (kondisi, kejadian, keadaan, dan tindakan) saling berinteraksi untuk menciptakan satu situasi tidak aman. Pada setiap situasi tidak aman ada saat kritis untuk mengambil keputusan yang pada akhirnya menentukan akibat dari situasi itu. Kadangkala, saat kritis ini terjadi jauh setclah situasi tidak aman diketahui. Makin besar intervalnya, makin besar pula potensi untuk menghindari kecelakaan. 
Ada beberapa kemungkinan yang dapat terjadi pada saat kritis ini. Kemungkinan pertama, terjadi kecelakaan dengan beberapa akibatnya, seperti meninggal dunia, cacat fisik, kerusakan jiwa, ketidakmampuan, kerugian ekonomi, dan kehilangan milik. Kemungkinan kedua, hampir terjadi kecelakaan. Akibat yang dapat ditimbul- kannya adalah stres, mendapat malu, takut, waswas atau lega, berterima kasih, dan belajar. Kemungkinan ketiga, tidak terjadi kecelakaan atau kecelakaan potensial. Hal yang demikian ini dapat mengembangkan kebiasaan yang tidak baik dan masa depan penuh dengan risiko. Orang merasa dirinya benar dengan, tindakan yang dilakukan- nya, karena semua berjalan dengan aman, walaupun itu sebenarnya palsu.

\section{PENUTUP}

Cedera olahraga merupakan sesuatu hal yang tidak diharapkan oleh siapa pun, oleh karena itu orang selalu berusaha menghindari atäu mencegahnya. Untuk mencegah terjadinya cedera orang harus mengetahui faktor-faktor penyebabnya terlebih dahulu, kemudian meniadakan faktor-faktor tersebut. Menurut teori model ekologi kecelakaan atau cedera disebabkan oleh faktor manusia dan faktor lingkungan.

Usaha pencegahan kecelakaan atau cedera harus dilakukan secara terpadu dan berjalan simultan dengan memperhatikan seluruh faktor yang terkai,, seperti yang di-amanatkan oleh teori model ekologi. Jika ingin selamat dalam melakukan aktivitas olahraga, orang harus memenuhi semua kebutuhan keselamatan yang diwajibkan dalam aktivitas tersebut. Hanya faktor "nasib" yang akan menggagalkan keselamatan manusia, apabila semua kebutuhan keselamatan sudah terpenuhi. 


\section{DAFTAR PUSTAKA}

Azrul Ananda. (2002). "Cegah Cedera Olahraga pada Anak." Jawa Pos. (23 April 2002). Halaman 20.

Bethesda. (2001). "Childhood Sports Injuries and Their Prevention: A Guide for Parents with Ideas for Kid." http:// wnv.niams.nih.gov/hi/topics/child sports/ child_sport.htm.

Bompa, T.O. (2000). Total Training for Young Champions. USA: Human Kinetics.

Congeni, J.A. (2004). "Dealing With Sports Injuries." http:/ kidshealth.org/teen/ food_fitness/ sports/sport_injuries.html.

. (2002). "Play It Safe Sport: A Guide to Safety for Young Athletes." bttp:// anvu.nlm.nih.gov/medlineplus/sportsafety.html.

Creighton, H. (1974). Health Education: Safety. Sydney: The Health Commision of MSW.

Dunkin, M.A. (2004). "Sports Injuries." http:// anvwniams.nih.gov/hi/topics/ sport_injuries/ SportsInjuries.ijisis.

Dwi Widijatmiko. (2005). "Satu Senti Lagi, Sheva Tewas!” Bola. (25 Februari 2005). Halaman 7.

Florio, A.E., dkk. (1979). Safety Education. New York: McGraw-Hill Book Company.

Giam, C.K. dan Teh, K.C. (1993). Ilmu Kedokteran Olabraga. (Hartono Satmoko. Terjemahan). Jakarta: Binarupa Aksara. Buku asli diterbitkan tahun 1992.

Huisenga, D. (2004). "Sports and Exercise Safety." http:/ kidshealth.org/teen/food fitness/ exercise/ sport safety.html.

Khoiron Fadil. (2002). "Wasit Kalah Cerdik, Pemain Babak Belur." Jawa Pos. (23 April 2002). Halaman 7.

Merki, M.B. (ed). (1996). Teen Health. Course 2. New York: McGraw-Hill.

Ritzei, D.O. (2003). "Assessing Definitions and Concepts Within the Safety Profess- ion." International Electronic Journal of Health Education/ wnw.iejhe.org.

Rusli Lutan. (2001). Penanggulangan Cedera Olabraga pada Anak Sekolah Dasar. Jakarta: Ditjen Olahraga.

Taylor, P.M. dan Taylor, D.K. (1997). Mencegah dan Mengatasi Cedera Olah- raga. (Jamal Khabib. Terjemahan). Jakarta: PT. Raja Grafindo Persada. Buku asli diterbitkan tahun 1997.

Yost, C.P. (ed). (1970). Sport Safety. Washington D.C.: The Association. 
